\title{
Planning of Heavy Equipment Fabrication Plant Layout using CORELAP Software: A case study of Indonesia
}

\author{
Bethriza Hanum \\ Faculty of Engineering \\ Industrial Engineering Department \\ Mercu Buana University, Indonesia
}

\begin{abstract}
According to the target, PT Heavy Equipment Ternama needs a good and smooth production system to support the fabrication process. Often the delivery time for boom components is not by the predetermined target, so it is necessary to improve to support the delivery target to the customer on time because the welding process is not optimal. The Engineering Department invests by adding one welding robot unit to support the production process to match the target. The addition of these new facilities requires re-planning the boom component processes and maximizing the distance between processes, which are currently less efficient, marked by long distances, and requiring a long time to move components between processes. The purpose of this research is to propose to improve the best factory layout with a comparison of the total distance of material movement between the initial layout and the proposed layout, which has an impact on changes in material handling costs. This study uses the CORELAP (Computerized Relationship Layout Planning) method to determine the best factory layout. The proposed new layout is the location between processes into one Production Line, which was previously on different Production Lines. This has an impact on reducing handling costs for one product which was originally Rp. 2,875,040 to Rp. 998,240 or decreased by $65 \%$, and the handling distance, which was originally $162 \mathrm{~m}$, became $98 \mathrm{~m}$ or decreased by $39.5 \%$ compared to the initial layout. PT Heavy Equipment Ternama from January to March 2020 can save handling costs of Rp. 296,534,400.
\end{abstract}

Keywords: Material Flow, Layout, Material Handling, CORELAP.

\section{INTRODUCTION}

In the industrial world, one of the things that companies need to pay attention to is the achievement of product delivery by the customer's desired schedule. PT. Heavy Equipment Leading in one pillar of its commitment is about Customer Oriented. The company upholds its commitment by making it one of the Key Performance Indicator targets for plant fabrication. One of the Key Performance Indicators for plant fabrication is the target delivery achievement for all components produced, 100\% [1-2-3]. Following are the achievements in 2019; see Figure 1 below

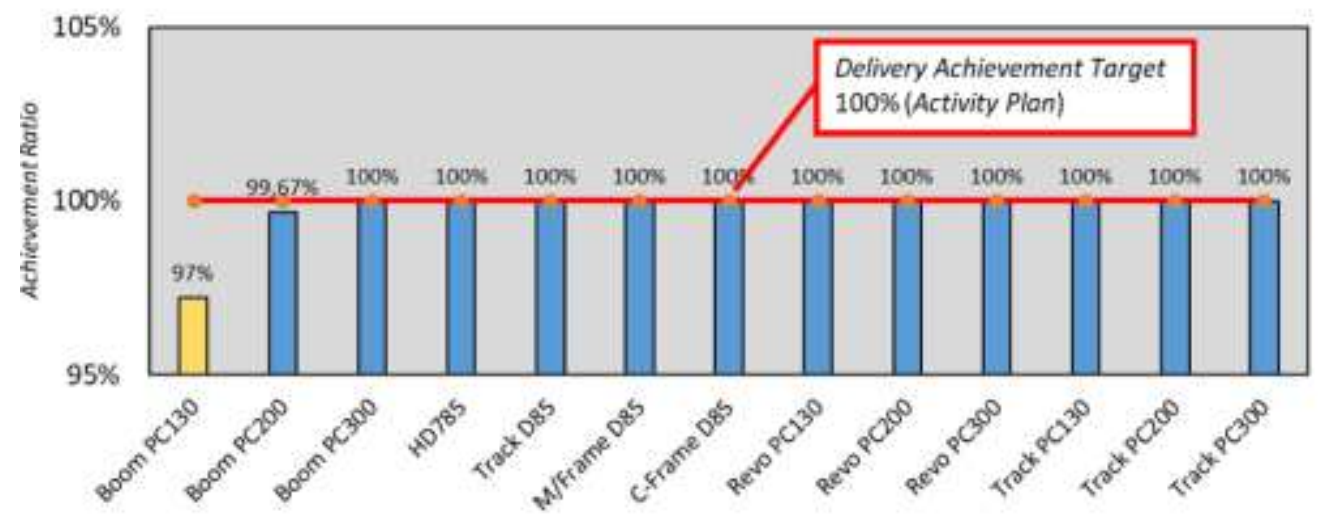

Figure 1 Data Average Delivery Achievement Plant Fabrication FY2019 
The data in Figure 1, which is collected in the 2019 production section of the fabrication section, the PC130 boom components have not achieved the delivery achievement target of $100 \%$. From the data in the image above, it can be seen that the PC130 boom component is the component that has the lowest delivery achievement record, which is $97 \%$. PC130 is heavy equipment that is included in the excavator type. PC130 products that are processed in-plant fabrication consist of 3 components, including Boom; from January to March 2020, PT Heavy Equipment Ternama produced 158 units of PC130 units. PC130 is the unit most made by the company for three months; production data can be seen in Figure 2 below:

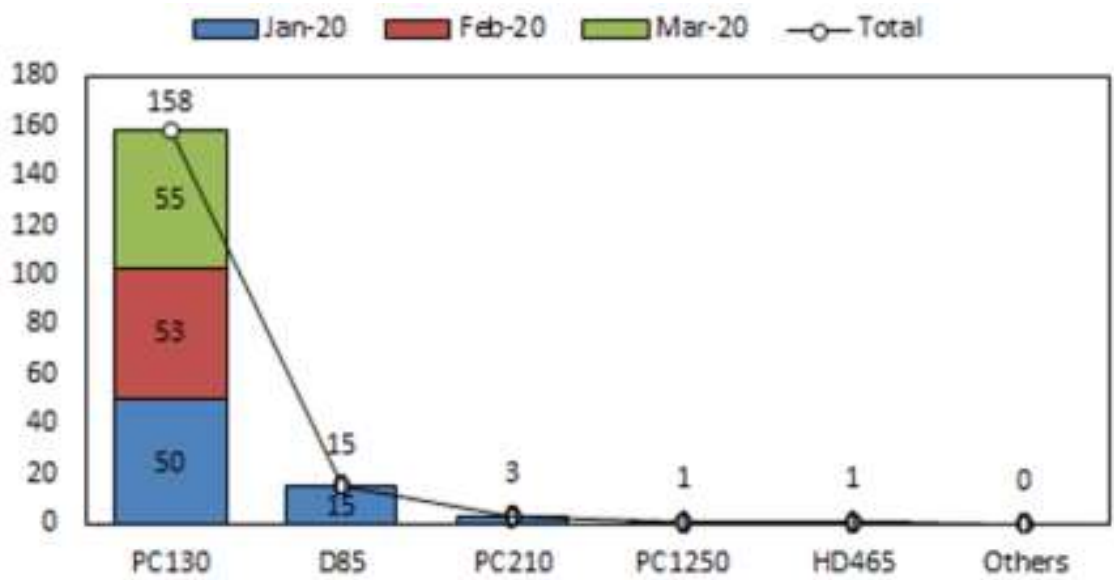

Figure 2 Number of Major Heavy Equipment Production January-March 2020

The number of PC130 units produced is relatively high. One of the boom components made is not following the target delivery achievement, based on the engineering section's analysis adding new facilities, namely a unique robot to process the PC130PC400 boom components. The addition of new facilities requires a new layout planning. The facility layout is one of the essential things in increasing productivity in a company. The layout of the factory facilities used in the company determines material handling. It determines the equipment and position of the production process in part as a basis for the production process's smooth running. The current layout conditions are shown in Figure 3below:

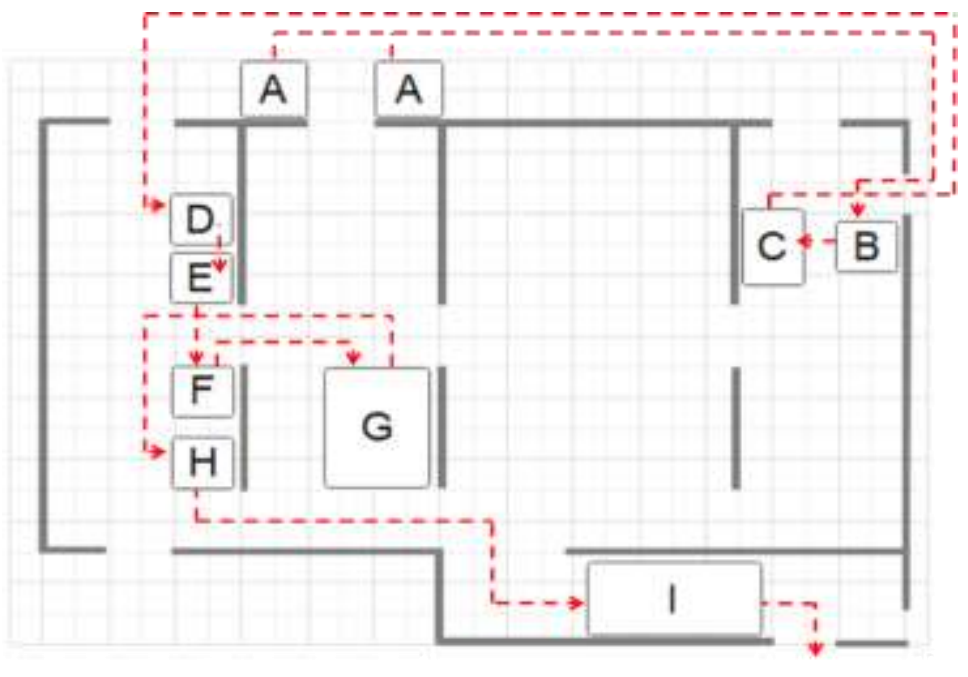

Figure 3 Layout of the Current Boom Process

Process Flow:

A = Raw Material Warehouse

$\mathrm{B}=$ Tack Welding Area 
$\mathrm{C}=$ Robot Automatic Welding (Old)

$\mathrm{D}=$ Semi Automatic Welding

$\mathrm{E}=$ Reinforce installation

$\mathrm{F}=$ Defect checking

$\mathrm{G}=$ Machining Process

$\mathrm{H}=$ Seat Installation

\section{I $\square=$ Coloring}

The researcher Rama dhani et al., states that making a good factory layout is proximity. Based on the production layout's current condition, the distance between departments is too far, so it is less efficient in the process. Planning for the best facility layout can support the production process to become smoother and more efficient [4-8]. The fabrication department takes into account the addition of new facilities to redesign the facility layout, with the distance between departments and the total distance being reduced to get benefits based on material handling [9-10]

\section{LITERATURE SURVEY}

\subsection{Factory Layout}

In the industrial world, the manufacturing process is essential in either the product or service business. This manufacturing process is primarily determined by the arrangement of the company's layout of the goods or physical facilities. This arrangement is very influential, especially for companies that produce a lot. Therefore, the science that includes regulating the arrangement of goods or physical facilities is the science of factory layout.

According to James M. Apple [11-12-13-14-15-16-17], factory layout designs and implements a production system of goods or services. This science's design is generally described by the layout design plan or arrangement of physical facilities, aiming to optimize the relationship between operators, material flow, methods to achieve company goals efficiently, economically, and safely.

The factory layout determines how a company carries out the production process. A production process that goes well and smoothly indicates that the production layout is appropriately organized and neat. One of the production activities is determined by the facility layout implemented by a company. Therefore, the level of efficiency and effectiveness of production demanded the facility's layout strongly influences high.

The factory layout is as optimal as possible because it cannot easily be changed according to particular circumstances. Therefore, the facility layout in a factory should be designed as much as possible for an indefinite period. According to Ramadhani [18-1920], the main objective of the facility layout is to regulate the work area of a company and all facilities used for the production process to increase economic value in a process, as well as create a sense of security, comfort, and increase the performance of an employee in doing production process. The advantages of planning a mature facility layout are as follows:

a) Increase production output

b) Reduces delay

c) Reducing the distance for the transfer of raw materials (material handling)

d) Saving the use of the area

e) Maximizing the use of machines, labor, and other production facilities.

f) Shorter manufacturing process

g) Reducing the risk of work accidents.

h) Creating a comfortable work environment.

i) Facilitate supervisor activity

\subsection{Working Method Layout}

In making a good factory layout, of course, there is an order and procedure. The science of plant layout is a science that has been invented for a very long time. Over time, plant layout experts found theories about making good factory layouts. One of them is Tompkins. According to Tompkins [21-22], the methods or ways to create a layout are:

1. Determine the problem

2. Analyze the problem

3. Creating an alternative design

4. Evaluating alternative designs 
5. Choose the design that will be used

6. Apply the selected design

2.3 CORELAP

Data processing with the CORELAP algorithm (Computerized Relationship Layout Planning) is done by creating an ARC to see each department's proximity relationship. The CORELAP (Computerized Relationship Layout Planning) algorithm is a construction algorithm, which is an algorithm used to produce new layout designs that do not depend on or do not require an initial layout. The calculation method uses the Blocplan 90 software tool and the Quantitative system 3.0 [23-24].

The research conducted emphasizes the details of the use of the CORELAP method. This research explains how the steps and processes to get the best layout proposal using the CORELAP method are based on previous research. Where the steps are arranged in order and detail in the research flow in Chapter III. Previous research has used manual methods to get the best layout of the proposal, but this study using the CORELAP 1.0 software. CORELAP 1.0 software that will provide the best layout suggestions based on algorithmic calculations. The first step is to determine the number of departments and the area of the department. Next is to add up the total area and add a number for the space area.

\section{RESEARCH METHODOLOGY}

\subsection{Type of Research}

Research conducted is to use quantitative research because this study uses variable numbers that come from measurements. Measurement data such as the area of space used in each production process and its effect on distance impact material handling costs.

\subsection{Types of Data and Information}

The types of data used in this study are primary and secondary data, namely:

1. Primary data

Sources of research data were obtained directly from the source in the form of observations during the study. Observations were made at PT Heavy Equipment Ternama on Plant Fabrication. The time of observation was in January - March 2020. The observations made were regarding the process flow of the PC130 boom component. The data required is about the area of each department and the distance and time between departments.

2. Secondary Data

Data sources are obtained through intermediary media or indirectly in books, notes, existing evidence, or archives, both published and not publicly published. The data obtained in this study were obtained based on monthly reports regarding delivery achievements during 2019, displayed in the cross-function room. This room is used to control the production of various sections, including production, I

\subsection{Data Collection Methods}

The data collection methods used are as follows:

1. Research in the field (Field Research)

In this method, data collection is carried out at PT. Alat Berat Ternama's Fabrication Plant measured the fabrication plant production room and observed the process directly on the PC130 boom component production line. Also, observations were made to see the initial layout of the existing facilities for each PC130 boom component manufacturing process.

2. Interview

In this method, data collection regarding process flow is obtained from interviews with the PC130 boom component operator who was directly involved during the fabrication process at the Fabrication Plant from November 2019 to January 2020. In addition, interviews were also conducted with the warehouse section to determine the position of the raw materials.

\subsection{Data Processing and Analysis Methods}

Data processing is carried out by following several stages, namely:

a. The depiction of the production floor is done by reviewing the current factory layout.

b. The calculation of the department's area is used to map the proposal's layout to suit the needs used to calculate the total area requirement. 
c. Production volume is needed to compare the total distance traveled by materials in the production process before and after the proposed new layout.

d. The total distance from the manufacture of a product is calculated based on the frequency of material movement in the production process. The total distance in material movement is obtained.

e. $\mathrm{OMH}$ is an analysis of material flow using measurements for every movement of material from one place to another. The cost of moving the material is calculated based on the distance traveled by the material to determine the amount of cost compared with the new proposed layout.

f. Perform material process flow analysis using Activity Relationship Chart (ARC) to find activity relationships between departments. ARC is used in the CORELAP method to calculate the relationship level.

g. Analyze the proposed layout of the new facility using the CORELAP 1.0 application. Decision-making on the proposed layout design that should be selected or applied. The steps to get the best layout with the CORELAP application are

1. Input the number of departments that will be re-arranged.

2. Enter the area of each department by the data collection that has been done.

3. Enter the relationship data of each department based on the ARC that has been made.

4. The best layout proposal based on the CORELAP 1.0 application can be applied by adjusting the existing area conditions.

h. Evaluating the proposed layout provided by the CORELAP 1.0 application to provide confidence that the decisions taken have provided an optimal alternative layout by calculating the OMH before and after the proposed new layout.

\section{RESULT AND DISCUSSION}

Based on the data that the researcher has processed, there is one layout of the proposal which is the result of the calculation of the CORELAP 1.0 software, where the layout of the proposal can be seen in the following figure after adjusting to the conditions of the plant fabrication building.

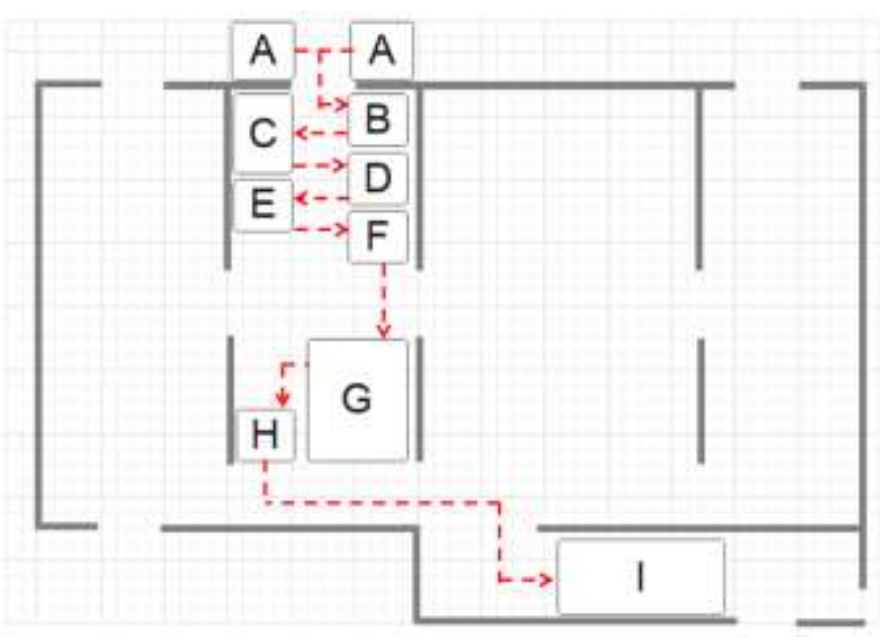

Figure 4 Proposed Layout

Table 1 Description of Facility Layout

\begin{tabular}{|c|l|}
\hline Departement Code & \multicolumn{1}{|c|}{ Departement } \\
\hline A & Raw material \\
\hline B & Tack Welding \\
\hline C & Automatic Welding Robot \\
\hline D & Semi-Automatic Welding \\
\hline E & Reinforce \\
\hline F & Defect Checking \\
\hline
\end{tabular}


International Journal of Engineering Research and Advanced Technology, Vol. 7, No. 6, June -2021

\begin{tabular}{|c|l|}
\hline Departement Code & \multicolumn{1}{|c|}{ Departement } \\
\hline G & Machinery \\
\hline H & Seat Installation \\
\hline I & Coloring \\
\hline
\end{tabular}

The initial facility layout of the department location for the PC130 boom component manufacturing process is contained in 3 production lines. A bulkhead separates each production line's condition, and the handling methods used are forklifts and overhead cranes. The proposed layout places the locations of each Department into one production line. The handling method used is a complete overhead crane without using a forklift.

The condition in one production line is that there are no dividers between departments because it facilitates the handling of components. For example, components measuring $5 \mathrm{mx} 0.5 \mathrm{mx} 1.5 \mathrm{~m}$ can be easily moved because each Department's position is close together, and there are no bulkheads.

The layout of the proposed facilities shows changes in the flow of more regular and close materials. These changes will affect the distance of material movement and minimum material handling costs to obtain an efficient production process.

Analysis of the Proposed Layout Mileage Analysis

Each Department that has been arranged into a new layout has a linkage process. This linkage is used to get the best layout to get the optimal mileage. The optimal mileage can be seen based on the following data:

Table 6.2 Calculation of Distance between Departments based on the Proposed LayoutBased on the data that the researcher has processed, there is one layout of the proposal which is the result of the calculation of the CORELAP 1.0 software, where the layout of the proposal can be seen in the following figure after adjusting to the conditions of the plant fabrication building.

Table 2 Calculation of Distance between Departments based on the Proposed Layout

\begin{tabular}{|c|c|c|c|c|}
\hline No. & Initial Station & $\begin{array}{c}\text { Desnatoin } \\
\text { Station }\end{array}$ & $\begin{array}{c}\text { Transport } \\
\text { Equioment }\end{array}$ & $\begin{array}{c}\text { Distance } \\
(\mathrm{m})\end{array}$ \\
\hline 1 & A & B & Manual & 12 \\
\hline 2 & B & C & Manual & 12 \\
\hline 3 & C & D & Manual & 12 \\
\hline 4 & D & E & Manual & 6 \\
\hline 5 & E & F & Manual & 8 \\
\hline 6 & F & G & Manual & 16 \\
\hline 7 & G & H & Manual & 11 \\
\hline 8 & H & I & & 21 \\
\hline
\end{tabular}

Table 3 Comparison of Material Mileage

\begin{tabular}{|c|c|c|c|}
\hline \multicolumn{2}{|c|}{ Mileage (m) } & Difference & Percentage \\
\hline Initial Layout & $\begin{array}{c}\text { Proposed } \\
\text { Layout }\end{array}$ & & of Decrease \\
& (m) & \\
\hline
\end{tabular}


International Journal of Engineering Research and Advanced Technology, Vol. 7, No. 6, June -2021

162

98

64

$39,5 \%$

Based on the table above, it can be explained that the mileage on the proposed facility layout is smaller than the initial facility layout, with a decrease in the percentage of $39.5 \%$ from the initial total distance of $162 \mathrm{~m}$ to $98 \mathrm{~m}$. In addition, mileage can be significantly reduced due to the proximity of the departments to each other and the absence of barriers, so the process of moving materials can take place at a close distance.

Analysis of Proposed Layout OMH

The following is a table for calculating material handling costs in the proposed facility layout:

Table 4 Material Handling Cost Calculation for Proposed Layout

\begin{tabular}{|c|c|c|c|c|c|c|c|}
\hline \multirow{2}{*}{ No. } & \multicolumn{2}{|c|}{ Station } & \multirow{2}{*}{$\begin{array}{l}\text { Transport } \\
\text { Equioment }\end{array}$} & \multirow{2}{*}{ Distance } & \multirow{2}{*}{ Time } & \multirow{2}{*}{ Salary/sec } & \multirow{2}{*}{ Cost/Unit } \\
\hline & From & to & & & & & \\
\hline 1 & $A$ & $B$ & Manual & 12 & 120 & 68 & Rp97.920 \\
\hline 2 & B & C & Manual & 12 & 120 & 68 & Rp97.920 \\
\hline 3 & $C$ & $D$ & Manual & 12 & 120 & 68 & Rp97.920 \\
\hline 4 & $D$ & $E$ & Manual & 6 & 60 & 68 & Rp24.480 \\
\hline 5 & $E$ & $\mathrm{~F}$ & Manual & 8 & 90 & 68 & Rp48.960 \\
\hline 6 & $\mathrm{~F}$ & $\mathrm{G}$ & Manual & 16 & 180 & 68 & Rp195.840 \\
\hline 7 & G & $\mathrm{H}$ & Manual & 11 & 120 & 68 & Rp87.040 \\
\hline 8 & $\mathrm{H}$ & 1 & Manual & 21 & 240 & 68 & Rp348.160 \\
\hline \multicolumn{7}{|c|}{ Total } & Rp998.240 \\
\hline
\end{tabular}

Based on this calculation, the cost required to move materials from station A to station B is IDR 97,920.

Table 5 Comparison of Material Handling Costs

\begin{tabular}{|c|c|c|c|}
\hline \multicolumn{2}{|c|}{ OMH } & \multirow{2}{*}{ Difference $(\mathrm{m})$} & $\begin{array}{c}\text { Percentage } \\
\text { of Decrease }\end{array}$ \\
\hline Initial Layout & $\begin{array}{c}\text { Proposed } \\
\text { Layout }\end{array}$ & \\
\hline Rp 2.875.040 & Rp998.240 & Rp 1.876.800 & $65 \%$ \\
\hline
\end{tabular}

Based on table 5.4, material handling costs were reduced by Rp. 1,876,800 in one cycle due to a reduction in the distance between materials moving between departments.

Company savings obtained based on production data from January 2020 to March 2020 are: 
Table 6 Total Savings for 3 Months

\begin{tabular}{|c|c|c|c|c|c|c|}
\hline No & Month & $\begin{array}{c}\text { Total } \\
\text { Production }\end{array}$ & & $\begin{array}{l}\text { f Old Layout } \\
\text { Handling }\end{array}$ & $\begin{array}{l}\text { Tota } \\
\text { Cost }\end{array}$ & $\begin{array}{l}\text { erial Handling } \\
\text { roposed New } \\
\text { youts }\end{array}$ \\
\hline 1 & January & 50 & $\mathrm{Rp}$ & 143.752 .000 & $\mathrm{Rp}$ & 49.912 .000 \\
\hline 2 & February & 53 & $\mathrm{Rp}$ & 152.377 .120 & $\mathrm{Rp}$ & 52.906 .720 \\
\hline 3 & March & 55 & $\mathrm{Rp}$ & 158.127 .200 & $\mathrm{Rp}$ & 54.903 .200 \\
\hline \multicolumn{3}{|c|}{ Total Cost } & $\mathrm{Rp}$ & 454.256 .320 & $\mathrm{Rp}$ & 157.721 .920 \\
\hline & & & \multicolumn{2}{|c|}{ Difference in cost } & $\mathrm{Rp}$ & 296.534 .400 \\
\hline
\end{tabular}

From table 5 it can be seen that the total savings for 3 months amounted to Rp. 295,534,400. Where in February 2020 has the highest total savings of Rp. 103,224,000 with a total production of 55 units.

\section{CONCLUSION}

Based on the discussion conducted, there are several conclusions obtained, namely:

1. There is the addition of a new facility, namely Robot Automatic Welding, so it is necessary to plan a re-arrangement of the facility, so using the CORELAP method can be given a proposal for the best facility layout. The automatic welding robot has been included in the planning by occupying the layout location with the department code $\mathrm{C}$.

2. The layout of the proposed facility provides the minimum possible distance compared to the initial layout distance. Based on the analysis results, the proposed facility layout resulted in a decrease in material mileage from $162 \mathrm{~m}$ to $98 \mathrm{~m}$ or a decrease of $39.5 \%$ for each component's process. Meanwhile, material handling costs for the initial facility layout amounted to Rp. 2,875,040, and the proposed facility layout was Rp. 998,240, or a decrease of $65 \%$ for each component's process.

5.2 Advice

The advice that the author can give is

1. We recommend that you carry out continuous improvements regarding process efficiency by utilizing existing facilities. Merging two processes with 2 locations into one can reduce processing time quite significantly.

2. The handling process, which is still far enough, should be improved by maximizing the speed of the handling system without compromising the level of security.

\section{ACKNOWLEDGMENT}

Universitas Mercu Buana Research Centre funded this research. We are grateful for all experts who are willing to be research partners, with no mention of the company name.

\section{REFERENCES}

[1] Alfa Firdaus., Dedy Pratama., 2013. Analysis of the design of the production floor layout of the welding division to increase production capacity at pt. Xx. Journal of synergy, 17(3), 268-274.

[2] Haekal, J., Hanum, B., \& Adi Prasetio, D. E. 2020. Analysis of Operator Body Posture Packaging Using Rapid Entire Body Assessment (REBA) Method: A Case Study of Pharmaceutical Company in Bogor, Indonesia. International Journal of Engineering Research and Advanced Technology - IJERAT (ISSN: 2454-6135), 6(7), 27-36.

[3] Hanum, B., Haekal, J., \& Adi Prasetio, D. E. . 2020. The Analysis of Implementation of Enterprise Resource Planning in the Warehouse Division of Trading and Service Companies, Indonesia . International Journal of Engineering Research and Advanced Technology - IJERAT (ISSN: 2454-6135), 6(7), 37-50. 
[4] Kholil, M., Haekal, J., Eko Adi Prasetio, D.., \& Sulaiman Hasan. 2020. The Lean Manufacturing Design For Improving Production Scheduling Using Product Wheel Method in Chemical Manufacturing Company, Indonesia. International Journal of Engineering Research and Advanced Technology - IJERAT (ISSN: 2454-6135), 6(8), 12-18.

[5] Haekal, J., \& Setio, H. 2017. Selection of Raw Material Suppliers Using Analytical Hierarchy Process in Food and Beverage Company, South Jakarta. ComTech: Computer, Mathematics and Engineering Applications, 8(2), 63-68.

[6] HAEKAL, J. (2018). Design and Evaluation of Iso 9001:2015 Quality Management System Implementation Through Customer Satisfaction at As-Syafi'iyah Islamic University (Doctoral dissertation, Mercu Buana University Jakarta).

[7] Kholil, M., Haekal, J. H, Sulaiman. 2020. Lean Manufacturing Design to Reduce Waste in Gear Production Process Using VSM and Kaizen Method Approaches (Case Study: Gear Primary Driven K56 Product). Journal of Scientific and Engineering Research. 7(8), 1-9

[8] Haekal, J., \& Prasetio, D. E. A. Planning Of Production Facilities Layouts In Home Industry With The Systematic Layout Planning Method.

[9] Haekal, J., \& Setiawan, I. (2020). Comparative Analysis of Raw Materials Control Using JIT and EOQ method For Cost Efficiency of Raw Material Supply in Automotive Components Company Bekasi, Indonesia. International Journal of Engineering Research and Advanced Technology (ijerat), 6(10), 76-82. https://doi.org/10.31695/IJERAT.2020.3661

[10] Haekal, J., Hanum, B., \& Adi Prasetio, D. E. 2020. Application of Quantitative Strategic Planning Matrix (QSPM) For Determination of Alternative Strategies in Food and Beverage SMES in Bogor Indonesia. Journal of Scientific and Engineering Research. 7(7), 137-145

[1] Ikatrinasari, Z. F., Hasibuan, S., \& Kosasih, K. (2018, November). The implementation of lean and green manufacturing through sustainable value stream mapping. In IOP Conference series: materials science and engineering (Vol. 453, No. 1, p. 012004). IOP Publishing.

[2] Ameha Mulugeta., Birhanu Beshah., \& Daniel Kitaw. 2013. Computerized Facilities Layout Design, Journal of EEA, 30, 2732.

[3] Durmusoglu, Z. D. (2018). A TOPSIS-based approach for sustainable layout design: activity relation chart evaluation. Kybernetes.

[4] Danang Triagus Setiyawan., Dalliya Hadlirotul Qudsiyyah., \& Siti Asmaul Mustaniroh., 2017. Proposed Improvement of Layout of Fried Soybean Production Facilities with BLOCPLAN and CORELAP Methods (Case Study on MMM UKM in Gading Kulon, Malang). Journal of Agroindustrial Technology and Management, 6, 51-60.

[5] Inaki Maulida Hakim. \& Vidyahningtyas Istiyanti. 2015. Improvement of Layout Production Facilities for A Secondary Packaging Area of A Pharmaceutical Company In Indonesia Using The Corelap Method. International Journal of Technology, 6, 1006-1016.

[6] James M. Apple. 1983, Plant Layout and Material Handling accessed at http://library.itats.ac.id//index.php?p=show_detail\&id=22672

[7] Md. Riyad Hossain., Md. Kamruzzaman Rasel., \& Subrata Talapatra. 2014. Increasing Productivity through Facility Layout Improvement using Systematic Layout Planning Pattern Theory. Journal of General Engineering, 14(7), 71-75.

[8] Nadia Dini Safitri., Zainal Ilmi., \& M. Amin Kadafi. 2017. Analysis of the layout design of production facilities using the activity relationship chart (ARC) method. Journal of Management, 9(1), 38-47.

[9] Qodri Azis Dwianto., Susy Susanty., \& Lisye Fitria. 2016. Proposed Facility Layout Design Using the Computerized

Relationship Layout Planning (Corelap) Method in a Convection Company. National Institute of Technology Online Journal. 4(1), 87-97.

[10] Salvendy, Gabriel, 1982, Handbook of Industrial Engineering accessed at http://amazon.com

[11] Srisuda Sinma., Anucha Watanapa., \& Wisitsree Wiyaratn. 2017. Increasing Productivity of Busbars manufacturing in

Switch Board Industry. TNI Journal of Engineering and Technology.5(1), 25-31

[12] Tomkins, 2003, Facilities Planning, John Wiley \& Sons, New York accessed at http://amazon.com

[13] Rahmadani, W. I. (2020). Warehouse Layout Redesign Using Conventional Methods, Collapsing And Promodel Simulation. Journal of Industrial Engineering Optimization (JOTI), 2(1), 13-18.

[14] Ikatrinasari, Z. F., Hasibuan, S., \& Kosasih, K. (2018, November). The implementation of lean and green manufacturing through sustainable value stream mapping. In IOP Conference series: materials science and engineering (Vol. 453, No. 1, p. 012004). IOP Publishing.

[15] Ameha Mulugeta., Birhanu Beshah., \& Daniel Kitaw. 2013. Computerized Facilities Layout Design, Journal of EEA, 30, 2732.

[16] Durmusoglu, Z. D. (2018). A TOPSIS-based approach for sustainable layout design: activity relation chart evaluation. Kybernetes.

[17] Danang Triagus Setiyawan., Dalliya Hadlirotul Qudsiyyah., \& Siti Asmaul Mustaniroh., 2017. Proposed Improvement of Layout of Fried Soybean Production Facilities with BLOCPLAN and CORELAP Methods (Case Study on MMM UKM in Gading Kulon, Malang). Journal of Agroindustrial Technology and Management, 6, 51-60. 
[18] Inaki Maulida Hakim. \& Vidyahningtyas Istiyanti. 2015. Improvement of Layout Production Facilities for A Secondary Packaging Area of A Pharmaceutical Company In Indonesia Using The Corelap Method. International Journal of Technology, 6, 1006-1016.

[19] James M. Apple. 1983, Plant Layout and Material Handling accessed at http://library.itats.ac.id//index.php?p=show_detail\&id=22672

[20] Md. Riyad Hossain., Md. Kamruzzaman Rasel., \& Subrata Talapatra. 2014. Increasing Productivity through Facility Layout Improvement using Systematic Layout Planning Pattern Theory. Journal of General Engineering, 14(7), 71-75.

[21] Nadia Dini Safitri., Zainal Ilmi., \& M. Amin Kadafi. 2017. Analysis of the layout design of production facilities using the activity relationship chart (ARC) method. Journal of Management, 9(1), 38-47.

[22] Qodri Azis Dwianto., Susy Susanty., \& Lisye Fitria. 2016. Proposed Facility Layout Design Using the Computerized

Relationship Layout Planning (Corelap) Method in a Convection Company. National Institute of Technology Online Journal. 4(1), 87-97.

[23] Salvendy, Gabriel, 1982, Handbook of Industrial Engineering accessed at http://amazon.com

[24] Srisuda Sinma., Anucha Watanapa., \& Wisitsree Wiyaratn. 2017. Increasing Productivity of Busbars manufacturing in Switch Board Industry. TNI Journal of Engineering and Technology.5(1), 25-31

[25] Tomkins, 2003, Facilities Planning, John Wiley \& Sons, New York accessed at http://amazon.com

[26] Rahmadani, W. I. (2020). Warehouse Layout Redesign Using Conventional Methods, Collapsing And Promodel Simulation. Journal of Industrial Engineering Optimization (JOTI), 2(1), 13-18.

C. Author EMAIL: Bethriza@mercubuana.ac.id 